\title{
State of My Opinion
}

\section{Noel Vera}

BusinessWorld

How did you start? In 1995, when I walked into the Manila Chronicle press room and turned in to Celine Cristobal-who was the lifestyle editor at the time-an article on Robert Zemeckis' Forrest Gump (hated it). Called two weeks later to ask if they accepted the story and was told they printed it that week. Have been writing ever since.

How often do you write? Once a week-more if, say, there is a special screening, or if a significant filmmaker has died and I feel he or she needs a tribute. Less if life happens to get in the way.

How do you prepare for the article? My methodology is ridiculously simple: Wikipedia to start; for biopics I hunt down articles comparing true story to adaptation. Issue films I read up on the issues. If the film is from a famed filmmaker or is done in a particular style I might read up on the filmmaker or style to refresh my memory or check for new developments. Sometimes I research on similar films in a particular genre, or films that have tackled a similar issue, or have used a similar approach. Really the commonsense approach-do your homework, or at least do a background check.

On the rare occasion I can talk to the filmmaker I will ask about budget, production problems, his opinion on the issues being tackled, etc. If there 
is something I know or suspect is autobiographical I will try asking about that. I try to be as upfront as possible that I cannot guarantee I will like the film-just that I will do my best to be fair.

How do you see the films? When I can, where I can. In a movie theater as much as possible, DVD or online streaming when it is not. Festivals are a golden resource-I will binge four, five, six films a day, midnight screenings. Film festival invitations do not come very often anymore.

How long do you take to write the article? As little as three to four hours, if I am lucky, when it is not a struggle. It helps if I have seen the film some time before and thought it over in my head. Also helps when I talk the film over with someone afterwards. If I'm lucky and I have time I can start a draft early and just think it through for a week or two, do research. I like to think you can see the difference, that the article is more carefully written and substantial.

Do you have a rating system? I love rating systems-well love to laugh at them. Stars, thumbs, popcorn buckets-it all seems silly to me. I would like to adopt one, just to parody its use ("Plus one star for the presence of actor $\mathrm{X}$, minus $1 / 2$ star for the failed toilet joke").

Do you know anyone in the industry and do you play other roles than critic in the industry? I do know a few critics, scholars, filmmakers. Maybe a handful of actors. We mostly have a casual acquaintance. We have also had disagreements and yes a filmmaker has been pissed at me for talking against his film-I understand, it's his baby that he's worked on for so hard for so long. I try to be polite as possible, making clear that's my opinion and it is also not going to change. Sometimes we reconcile.

I have done translations and subtitling. I have done scripts. I have acted in one film, a brief scene. I have been a jurist. I have recommended films to festivals, provided film prints (to Munich, if I remember right), and did a program for [International Film Festival] Rotterdam. Not a lot but enough. 
Do you have another job? I work full-time at a placement for at-risk youths, male and female; I am an overnight supervisor. It is interesting work and pays fairly well.

\section{What is the state of Filipino film criticism? Of Filipino filmmaking?}

Filipino film criticism has evolved. We have lost some of our best peopleHammy Sotto and Gino Dormiendo come to mind-while others seem to have grown inactive, thanks to the rise of free film blogs, of Letterboxd (where anyone with internet access can put up a movie review), and of YouTube reviewers. I am glad to see the rise of serious writers on Filipino films-I am thinking of Oggs Cruz at Rappler, and of Adrian Mendizabal, who writes on film from a philosophical perspective. New generation seems to have sprouted and they are as ambitious and creative as any of us; what is missing is historical perspective, a sense of what Filipino films were like in earlier decades. Think about it - the number of people who have seen a film on $35 \mathrm{~mm}$ is gradually diminishing.

At the same time films from the past have been recovered-I am thinking of Gerardo de Leon's Noli Me Tangere among others. Mike de Leon has been posting old films in installments on his Facebook page Casa Grande Vintage Filipino Cinema-that is a gold mine of perspective there, much of it digitally stored and available online.

And same time as all this the independent scene is-well, not flourishing, but definitely surviving, and as ambitious and inventive as ever. Jerrold Tarog, Antoinette Jadaone, Khavn, Denise O’Hara, Raya Martin, Keith Sicat, Sari Dalena, Richard Somes, John Torres, Lav Diaz-more names and more styles than I have room or memory to cite. Chito Roño and Joel Lamangan are still active; Mike de Leon came out with a film last year, after eighteen years. Plenty to write about.

What's your present status as a film critic? Since my move to the USA I mostly regard myself as an outsider looking in-I have to; I do not see all the Filipino films I want to. I like to think myself as a kind of bridge between 
local and international cinema, that I can see what Hollywood is up to and judge it according to the strength and creativity of our own filmmakers; at the same time I can see what our filmmakers are doing and put it in context of international cinema.

What's your methodology for evaluating films? I do not have any one set method for critical evaluation-I do subscribe to the auteurist school of thinking in regarding the director as often being the prime author, though I have seen cases where the writer or actor have had significant or even dominating influence over a production. I consider political themes, social themes; I consider aesthetic approach. Depending on the kind of film it isarthouse or multiplex -I consider what its aims are (Entertain? Instruct? Break new ground?). Then I sometimes switch things around and look at the picture from a different viewpoint.

Where do you get these approaches? From wherever I can-Pauline Kael was an early influence; same with James Agee. I learned to read Dave Kehr, Jonathan Rosenbaum, Stanley Kauffmann, David Bordwell, Joel David, Hammy Sotto, and Nick Deocampo, and I have talked to Filipino filmmakers about approaches and inspirations.

What is my goal in writing? To keep myself sane. Because if I do not write, if I do not express my thoughts and feelings about what I have heard and seen, I will explode-literally, I sometimes think. I achieve peace and emotional balance by letting out the bile and blessings through my pen (or keyboard if you like).

I prefer not to focus on one kind of film, just to keep my diet varied. I will admit to having a bias towards independent and genre films (science fiction, horror, fantasy, comedy, action), and to a bias towards Filipino films-but being aware of that, I look at what I can, when I can.

What is a well-made film? I hesitate to say-I am afraid I will box myself in. A coherent, well-written script would be nice; imaginative directing and 
camerawork would be nice; honest and skilled acting would be nice, but all that can get tossed out if the director has a strong enough idea. StraubHuillet's Europa 2005 - 27 octobre has a camera move down a street to an electrical transformer; that is it. You had to know in advance that the transformer killed two youths being chased by police. Was it a good film? Does having to know the information beforehand make it bad? I thought it was a powerful experience, mysterious and beautiful. Could I be fooling myself that I saw something great? I do not know; after all these years, I do not know all the answers. 


\section{Works Cited}

Europa 2005-27 octobre. Directed by Jean-Marie Straub and Danièle Huillet [uncredited], Rai 3, 2006.

Forrest Gump. Directed by Robert Zemeckis, Paramount Pictures, 1994.

Noli Me Tangere. Directed by Gerardo De Leon, Bayanihan Film Productions \& Arriba Productions, 1961. 